\title{
COMPUTER-ASSISTED AUDIT TECHNIQUES: MAIN ADVANTAGES AND DISADVANTAGES
}

\author{
Y. Serpeninova, Associate Professor at the Accounting and Taxation department, \\ Sumy State University, \\ Rymskogo-Korsakova str., 2, Sumy, 40007, Ukraine \\ S. Makarenko, Postgraduate student at the Economic Cybernitics Department \\ Sumy State University, \\ Rymskogo-Korsakova str., 2, Sumy, 40007, Ukraine \\ M.Litvinova, master student \\ Sumy State University, \\ Rymskogo-Korsakova str., 2, Sumy, 40007, Ukraine
}

The authors substantiate the positive role of information technology in auditing and computer-assisted audit techniques for decision-making during various audit procedures. It is established that the International Auditing Practice Regulation IASP - "Computer Assisted Audit Techniques" play a fundamental role in regulating their use by auditors during rendering assurance and other related services. It was proved, that the auditors use computerassisted audit techniques for various reasons. Moreover, it helps them to better plan and prepare themselves for all the challenges that today's competing environment is bringing to them The key advantages of using computerassisted audit techniques are substantiated, which are mainly refer to improving the efficiency and reliability of the auditor's work, reduce its complexity. Additional advantages concern the ability to create electronic worksheets on a centralized database, the possibility to detect fraud, continuous monitoring as a constant process of accumulating, analysing and reporting company database, testing the client's accounting software, testing of bulky volumes of database in a short time and with good accuracy, testing the database source, making comparisons between the results obtained swallow computer-assisted techniques and the results of classical tests, the ability to check specific risk. In contrast the most significant disadvantages and obstacles to the use of computer-assisted audit techniques were characterized. They are associated with high cost and complexity of implementation technologies as well as high initial cost of installation and maintaining computer-assisted audit techniques, inadequacy of simplified accounting software, overstatement of investigations, and high requirements to effectiveness of client database.

Keywords: audit, information technology in audit, computer-assisted audit techniques.

DOI: $10.21272 / 1817-9215.2019 .3-8$

\section{INTRODUCTION}

The corporate world is getting more and more inclined towards the hold of information technology (IT) and computer information organization in their vital operation for the intention of processing of data, as well as decision-making, and checkup of business organizations. The evolution of computer technology contributed to its execution in all ranges of human life. Capability of computers quickly processes bulky contents of information and react promptly to alters in certain indicators in accordance with the established platform has led to their assume in various sectors of the economy, including in the accounting sector.

In foretime, auditors' and accounters' computer skills were limited to auditing near the computer (printing and scrutinizing the information) and using the computer as an administrative instrument. The fast up growth in data contents has increased the necessity for auditors to alter their audit advance by involving powerful software applications in the realization of the audit. Today, in accordance with Gelinas, Davis and Knechel, software appliques are widely utilized by auditors and it is essential for potential auditors (auditing students) to get the obligatory exposure [3].

Veerankutty [10], Nearon, [13]. Kotb and Roberts [9], Abidin [5], Janvrin and Bierstaker, $[1,7]$, Sundgren and Svanström, [14], Moorthy et al. [12], Venkatesh et al [15] provide a large piece of evidence in IT in audit activities. Nevertheless, current peculiarities of their using (advantages and disadvantages type of accounting firms) are not discussed enough.

Various methodologies of scientists to designate the conception of IT audit, its role and need in the practitioner field of bookkeepers and auditors were considered as well as their advantages and disadvantages. Cleverness this locality will facilitate the work of 
professionals and make it more multifaceted and effective in a rapidly originating environment.

The current study is significant as the fast progression of IT results in higher requirement of computer-assisted audit techniques (CAATs) for auditing. Essentially, auditors use CAATs for various reasons. Moreover, it helps them to better plan and prepare themselves for all the challenges that today's competing environment is bringing to them.

\section{GOALS}

The objective of this work is to describe IT audit process with a CAAT review, research of nature of different audit techniques and advantages and disadvantages of their adoption on the level of organization.

\section{RESULTS}

Today, in a computerized epoch, the need arises for the auditor to extract an opinion based on real-time information, instead of the classical historical methodology. The auditor needs to consider qualitative information produced by information organizations, as pressures come, in this respect, both from the internal administration and the external shareholders, who need to be informed to withstand opposition.

As business intelligence organizations are increasingly used by economic entities, the auditors' interest in them expansions as well, along with the need to distinguish and understand all operations and practices recorded by the computerized organization, which, according to the auditor's decision, may be significant for the financial statements [15]. In common, business intelligence refers to software designed to assist managerial resolution through an organization able to manage the information available in an organization.

Auditing Practice Regulation 1009 "Computer-Assisted Audit Techniques" is originated based on the International Auditing Practice Regulation IASP - "Computer Assisted Audit Techniques") approved by the International Federation of Accountants (IFAC) in the 2001 edition [6].

Computer-assisted audit methods can be defined as a computer - based tools designed to improve the efficiency and performance of the audit process and it is a growing field in the 21st century [9]. These techniques include basic office software, spreadsheets and word processors, as well as advanced software platforms including smart tools for business, able to perform statistical analysis, in corresponding with the evolution of specialized audit software platforms.

CAAT is a fundamental step ahead from the examination of financial statements and customer confirmation operations, as these classical methods are based on a small segment of the operations and may not always reflect the real situation of the entity in the audited period, despite the auditors' hard work and professionalism. Exploit computerized applications, the auditors originate a clearer picture of the customer's "business" as they are able to verify bulky volumes of database, classify them according to certain criteria, they may issue statistics and even prognostications, being provided with a complex picture of the audited company [8].

When auditors choose their work instruments, they should evaluate the following characteristics: ease of use in practice, ease of database retrieval, the ability to access a wide range of database files on different platforms, the ability to integrate database in a different format, the ability to define fields and select from standard formats, menu functionality to process analysis orders, setup and changes of simplified questionnaires.

The classical auditing method admits auditors to reach a reasonable conclusion based on a limited tester of a population but does not admit exhaustive examination of a tester or of all available database. Application small testers can dwindle efficiency of the final conclusions, but the auditor states that tester selection is based on commonly accepted auditing standards and then the tester is statistically valid [11].

CAAT solve this problem as they are able to analyze bulky volumes of database to distinguish errors. An audit based on these techniques will not examine a tester, but all 
operations of the audited entity in the period under audit. Then the auditor tests the database to distinguish possible anomalies - for instance you can find VAT registration codes wrongly recorded by connecting your organization to the national database or erroneously duplicated operations by applying spreadsheets. Distinguishing these potential problems, the auditor can address the administration stating that $100 \%$ of operations have been tested and $100 \%$ of anomalies have been identified [15].

When application computer-assisted audit techniques, the auditor discovers that work is improved and made more efficient, as it benefits from many advantages compared to the classical verification organization. On the other hand, CAAT also has a number of drawbacks. Advantages and disadvantages of swallow CAATs are presented in Table 1.

Since computerized auditing techniques have a number of contradictory points, more or less disadvantages and advantages, the auditor should take this into account. Before carrying out an audit of an object, it must clearly distinguish whether it is obligatory to use the suitable techniques, or it is expedient not to use them. It also depends on the specifics of the enterprise's activities and their scope, the functioning of internal control services and other.

\section{Table 1 - CAAT's advantages and disadvantages in auditing activities}

\begin{tabular}{|l|l|}
\hline \multicolumn{1}{|c|}{ Advantages } & \multicolumn{1}{c|}{ Disadvantages } \\
\hline - Electronic worksheets on a centralized database. & - High costs for installing. \\
- Avoiding fraud through database analysis. & - Inadequacy of simplified accounting software. \\
- Continuous monitoring. & - Expensive software changes. \\
- Effective use of time. & - Exaggeration of investigations it too high-- priced \\
- Work with primary documents. & programs. \\
- Cost effectiveness. & - Possible problems with client database. \\
- Comparison of the results of the auditor's work. & \\
- Test specific risks. & \\
\hline
\end{tabular}

Thereby, among the benefits of swallow these methods have been included:

- the ability to create electronic worksheets on a centralized database, inside which the auditor may coordinate current audits and can access information from past or similar projects. In addition, the auditor will use a standardized audit report format, which improves the quality of the worksheets;

- the possibility to detect fraud through the use of tools that can distinguish unexpected or unexplained patterns in the audited database. No matter how simple or complicated the computer techniques used, computerized database analysis provides many benefits in the prevention and detection of fraud;

- continuous monitoring as a constant process of accumulating, analyzing and reporting company database in order to distinguish business operational risk. Auditors are provided with a comprehensive database organization as long as they make sure that the administration continuously monitors activities on all computer organizations, on all operations and applications used.

- testing the client's accounting software, as the auditor can verify whether it works correctly or not, since the volume of operations subject to auditing is extremely high. The only effective way to test the client's platform is by application computer-assisted techniques;

- testing of bulky volumes of database in a short time and with good accuracy, so that the auditor has more confidence in his opinion;

- testing the database source, as the auditor can test the accounting platform and its records directly at their origin, rather than testing paper documents that are supposed to be accurate replicas;

- cost effectiveness because, once an audit software is implemented, it can be used year after year to obtain audit argument, provided the client does not regularly change their accounting software;

- making comparisons between the results obtained swallow computer-assisted techniques and the results of classical tests. If similar results are obtained, the auditor's common confidence will grow; 
- the ability to check specific risks. For instance, when the auditor must verify issued invoices: the classical method admits the auditor to randomly select a "statistically valid" tester of 100 invoices from various moments of the audited period. Since the total number of invoices may exceed 3,000, chances are very small to detect all possible errors in the selected tester. Instead, swallow computer-assisted techniques, the auditor can check all 3,000 invoices and will surely distinguish all existing errors [2].

Besides, the auditor is not the only one to benefit from these advantages. The audited entity also acquires more certainty regarding the accuracy of the operations and the extent to which they comply with existing policies. By constant use of automatic operation analysis and through continuous monitoring, these techniques admit testing and validating of critical company database, independently and in real time. The administration of the audited entity may use this information to proactively distinguish exceptions and take immediate action to meet standards, while the implementation of these platforms help increase confidence in the database underlying the financial statements [12].

Obviously, the financial auditor may encounter more or less hardship in application audit software:

- high implementation costs: the initial cost is high because you need to inspect and understand the client's operations before swallow the audit software to access and query those files;

- changes are expensive, meaning that if the client changes the accounting software, then the audit software will require changes as well and they are not cheap;

- inadequacy of simplified accounting software: it is unlikely for the auditor to use an audit software suitable to a simplified accounting platform. As a simplified software does not provide complete information, it is very heavy for the auditor to distinguish all operations. It will be hard to justify the cost of a special audit software to test these platforms considering the possible benefits of the audit or the possibilities to recover the costs of this software;

- overstatement of investigations: the tendency to produce overly laborious investigative, too expensive platforms, in which processing and reviewing take too long. All these increase audit costs, without justifying utility - the volume of results: in the end the results might have a too high volume, either because of poor software design or because of application the wrong parameters in a test. In this way, the auditor will lose too much time to decide what is relevant from this bulky volume of results;

- client database: the audit software must run on an effective client database for the auditor to test the client's existing accounting platform. More or less customers might not admit auditors to run the audit software directly on the actual files for fear they would corrupt their database. The alternative solution is for the audit platform to run on a backup copy of the actual database, provided that the copied files are identical to those from the client's database [4].

Also, we must stress that the analysis application these auditing techniques is limited to database stored on a systematical pattern. Unfortunately, few databases are recorded in this manner and the available database usually lacks information or is incompletely classified, may be heavy to access or database integrity is doubtable. Therefore computer-assisted audit techniques are currently used along with the other classical techniques and instruments [Ismail, N. A. (2009). Factors influencing AIS effectiveness among manufacturing SMEs: Evidence from Malaysia. The Electronic Journal of Information Systems in Developing Countries, 38(10), 1-19.]. There are audits in which computer-assisted techniques cannot be used at all, as well as audits which cannot be performed efficiently and relevantly without these techniques.

In-depth knowledge of the facilities offered by spreadsheet applications can bring significant saving of time and resources to a wide range of users. The modern auditor who, almost without exception, carries a significant part of his work by testing database, can greatly benefit from swallow these facilities [4]. 
Business intelligence and CAAT provide auditors with the expertise and tools obligatory to comply with new regulations and standards, both professional and IT, helping them collect information quickly and in real time, and understand the client's work and environment. As long as auditors obtain, process and analyze information faster than with classical methods, the quality of the audit mission is increased, and risks are reduced.

\section{CONCLUSIONS}

Presently, computer is used as an ideal technology in various professions since it does its job with more accuracy and speed than what humans do. Many organizations have opted to utilize sophisticated information technologies for developing their business process support as well as improving their information processing activities. This increases the need for CAATs in such businesses to admit auditors to proceed to be able to comply their review and monitoring tasks effectively, as well as to play key roles in the cause of innovation in these businesses more generally.

Over the past few years, the number of employees who have never experienced advanced audit methods has been reduced. This phenomenon continues to gain popularity and has many advantages, such as cost effectiveness, maintaining of test specific risks, effective use of time. CAATs help to avoid fraud through database analysis and do all auditors work in a single database.

Despite the high costs of implementing CAATs, costs for the work of the entire audit activity of the company are reduced by increasing productivity and reducing the number of errors in the audit process.

Nowadays, a fairly wide range of software has been invented for specific tasks. For example, one software was created in order to exist an audit in certain industries and with a certain set of audit procedures, the other - more extensive use and is used so that they can be used by a large number of clients (the same employees of the company).

The acceptance and usage of CAATs between auditors is very momentous, because CAATs increase audit effectiveness and efficiency. Latter audit standards encourage auditors to adopt CAATs to perfect audit efficiency and effectiveness. Prior CAAT research is generally descriptive in nature. Research carried out proposes that CAATs acceptance is fairly low and differentiates among firms.

\section{АНОТАЦІЯ}

Авторами обтрунтовано позитивну роль інформаційних технологій в аудиті та комп'ютерних методах аудиту для прийняття рімень під час різних аудиторських прочедур. Встановлено, щзо Міжнародне положення з аудиторської практики «Комп 'ютеризовані методи в аудиті» відіграє основоположну роль в регламентаиії їх застосування аудиторами під час виконання завдань з надання впевненості та інших супутніх послуг. Було доведено, щзо аудитори використовують комп'ютерні методи аудиту з різних причин. Більше того, це допомагає їм краще планувати та підготуватися до всіх викликів, щуо постає перед ними конкуруючим середовищем. Обгрунтовані ключові переваги використання комп'ютерних методів аудиту, які в основному стосуються підвищення ефективності та надійності роботи аудитора. Додаткові переваги стосуються можливості створення електронних аркушів на иентралізованій базі даних, можливості виявлення шахрайства, постійного моніторингу як постійного процесу накопичення, аналізу та звітності бази даних компанії, тестування бухгалтерського програмного забезпечення клієнта, тестування об'ємних обсягів бази даних за короткий час вчасно та з хорошою точністю тестування джерела бази даних, порівняння між отриманими результатами проковтування комп'ютерних методик та результатами класичних тестів, здатністю перевіряти конкретний ризик. Також були охарактеризовані найбільш значні недоліки та перешкоди для використання комп'ютерних методів аудиту. Вони пов'язані з високою вартістю та складністю технологій впровадження, а також високими початковими витратами на встановлення та підтримку комп'ютерних методів аудиту, недостатністю спрощеного програмного забезпечення бухгалтерського обліку, високими вимогами до ефективності клієнтської бази даних.

Ключові слова: аудит, інформаційні технологї̈ в аудиті, комп'ютеризовані аудиторські техніки $i$ методи.

\section{СПИСОК ЛІТЕРАТУРИ}

1. Bierstaker, J., Janvrin, D., \& Love, D. (2014). What factors influence auditors' use of computer-assisted audit techniques. Advances in Accounting, 30(1), 67-74. https://doi.org/10.1016/j.adiac.2013.12.005. 
2. Curtis, M. B., \& Payne, E. A. (2008). An examination of contextual factors and individual characteristics affecting technology implementation decisions in auditing. International Journal of Accounting Information Systems, 9(2), 104-121. http://dx.doi.org/10.1016/j.accinf.2007.10.002

3. Gelinas, Davis, Knechel (2014). Business processes and information technology. Mason, OH: South-Western

4. Hartono, J. (2012). Adoption of information technology on small businesses: The role of environment, organizational and leader determinant. International Journal of Business, Humanities, and Technology, 2(4).

5. Ismail, N.A., \& Abidin, A.Z. (2009). Perception towards the importance and knowledge of information technology among auditors in Malaysia. Journal of Accounting and Taxation, 1(4), 61-69.

6. Janvrin, D., Bierstaker, J. and Lowe, J. (2014), "An investigation of factors influencing the use of computerrelated audit procedures”, Journal of Information Systems, Vol. 23 No. 1, pp. 97-118.

7. Janvrin, D., Bierstaker, J., \& Love, D. (2008). An examination of audit information technology use and perceived importance. Accounting Horizons, 22(1), 1-21. https://doi.org/10.2308/acch.2008.22.1.1

8. Kim, H. J., Mannino, M., \& Nieschwietz, R. J. (2009). Information technology Ismail, N.A., \& Abidin, A.Z (2009). Perception towards the importance and knowledge of information technology among auditors in Malaysia. Journal of Accounting and Taxation, 1(4), 61-69

9. Kotb and Roberts, C. (2011). The impact of E-business on the audit process: An investigation of the factors leading to change. International Journal of Auditing, 15, 150-175.

10. Mahzan N. and Veerankutty F. (2011) IT Auditing Activities of Public Sector Auditors in Malaysia African Journal of Business Management 5 pp 1551-1563

11. Mahzan, N., Muhammad, R., Shahimi, S., Yahya, Y., \& Ahmad Radzi, N. (2009). 2008 survey report on CAATTs usage by internal auditors in Malaysia. Keeping in Touch, Institute of Internal Auditors Malaysia

12. Moorthy, M. K., Seetharaman, A., Mohamed, Z., Gopalan, M., \& San, L. H. (2011). The impact of information technology on internal auditing. African Journal of Business Management, 5(9), 3523-3539

13. Nearon (2009). The role of internal auditors in ERP-Based organizations. Journal of Accounting and Organizational Change, 5 (4), 514-526.

14. Sundgren, S., \& Svanström, T. (2010). Auditor-In-Charge Characteristics and Going Concern Reporting Behavior: Does number of assignments, age and client fee dependence matter. Contemporary Accounting Research, 31(2), 531-550. https://doi.org/10.1111/1911-3846.12035.

15. Venkatesh, V., \& Bala, H. (2012). Adoption and impacts of interorganizational business process standards: Role of partnering synergy. Information Systems Research, 1-27. http://dx.doi.org/10.1287/ isre.1110.0404. 